\title{
New insights concerning homology of the oral region and ambulacral system plating of pentaradial echinoderms
}

\author{
Colin D. Sumrall \\ Department of Earth and Planetary Sciences, The University of Tennessee, 1412 Circle Dr., Knoxville, Tennessee 37996, USA 〈csumrall@ utk.edu〉
}

\begin{abstract}
Universal elemental homology (UEH) underpins recent understanding of peristomial and ambulacral elemental homology of pentaradiate echinoderms by providing a uniform set of terminology to construct phylogenetic characters. Variation in the expression of these elements provides evidence for phylogenetic relationships. Two nonhomologous sets of plates border the peristome and are associated with two nonhomologous sets of floor plates forming the ambulacral food groove. Some edrioasteroid-grade and eocrinoid-grade echinoderms have ambulacral systems formed from oral frame plates and adradial floor plates, whereas most blastozoans and crinoids bear oral plates and abradial floor plates. These plates are expressed in a variety of ways among echinoderms, but nearly all can be reconciled with the underlying model. Arguments against UEH are methodologically flawed and confuse many terms and interpretations.
\end{abstract}

\section{Introduction}

Inferring phylogenetic relationships of any clade using morphological data cannot be done in the absence of an accurate understanding of homology. In Paleozoic echinoderms, assessing homology is particularly challenging because: (1) the process of evolution often masks homology via character transformation, and (2) a striking proliferation of taxonomic 'classes' based on unique combinations of morphological characters has emphasized differences rather than underlying similarities. Unfortunately, many of these classes have unique sets of terminology, which apply different names to homologous structures or identical names to nonhomologous structures (Sumrall, 2010; Sumrall and Waters, 2012). Recently, the universal elemental homology (UEH) model provided a morphologic framework to facilitate the identification of individual echinoderm skeletal elements associated with the mouth region and ambulacral system (Sumrall, 2010, 2015; Sumrall and Waters, 2012; Kammer et al., 2013; Ausich and Kammer, 2016). With this model based on detailed anatomy, symmetry, and development, evolved differences in plate relationships, morphology, and presence/absence of plates can be identified with high precision and utilized to construct useful phylogenetic characters.

This paper summarizes various taxa of derived pentaradiate echinoderms and shows how UEH can be used to describe characters within this high-resolution framework. Of particular interest is the recognition of two nonhomologous sets of floor plates that make up the food groove. A few taxa (early edrioasteroid-grade echinoderms and asterozoans) bear both an adradial and abradial floor plate set on either side of the perradial suture. Many later taxa lose one of these sets, and these losses correlate to the plate series forming the peristomial border.

Generally, the skeleton of pentaradial echinoderms can be divided into axial skeleton, associated with the peristome (mouth opening) and ambulacral system, and the extraxial skeleton, comprising the rest of the body wall (Mooi et al., 1994, 2005; Mooi and David, 1997, 1998, 2008; David and Mooi, 1998; David et al., 2000). The UEH model strictly relates to elements of the axial skeleton of these echinoderms. Within the pentaradial clade, the axial skeleton is constructed from several different plate series (Fig. 1). The peristomial opening is bordered by some combination of radially positioned oral frame plates and interradially positioned oral plates (Kammer et al., 2013). These two circlets are demonstrably not homologous by conjunction (Patterson, 1988) as they occur simultaneously in several taxa, such as edrioasterids. Distal to the peristomial border lie radial or perradial floor plates that form the food groove and often mounting sites for small feeding appendages called brachioles (Fig. 1.1). Most taxa bear some combination of floor plates that are of two types, either the adradial (inner) set or the abradial (outer) set. These two floor plate types are demonstrably not homologous by conjunction (Patterson, 1988) as they occur simultaneously in several taxa, such as Kailidiscus, pyrgocystid edrioasteroids, and asteroids (Zhao et al., 2010; Sumrall and Zamora, 2011). These floor plate sets form a continuous plate series with either the oral plate series (abradial) or the oral frame plate series (adradial), respectively, suggesting they form part of the same developmental sequence. Covering the peristome and ambulacral system is a series of plates that protect the food groove. Proximally, the peristome is roofed by interradially positioned primary peristomial cover plates (PPCP) forming the center of the cover plate series (Fig. 1.1, 1.3). Ambulacral cover plates mount directly to the peristomial bordering plates and floor plates forming a roof to the ambulacral system. Fundamental bilateral symmetry of the ambulacral system results in these plates being aligned to the underlying ambulacral designations. This allows individual plates to be precisely identified and traced developmentally and phylogenetically (Sumrall and Waters, 2012). 

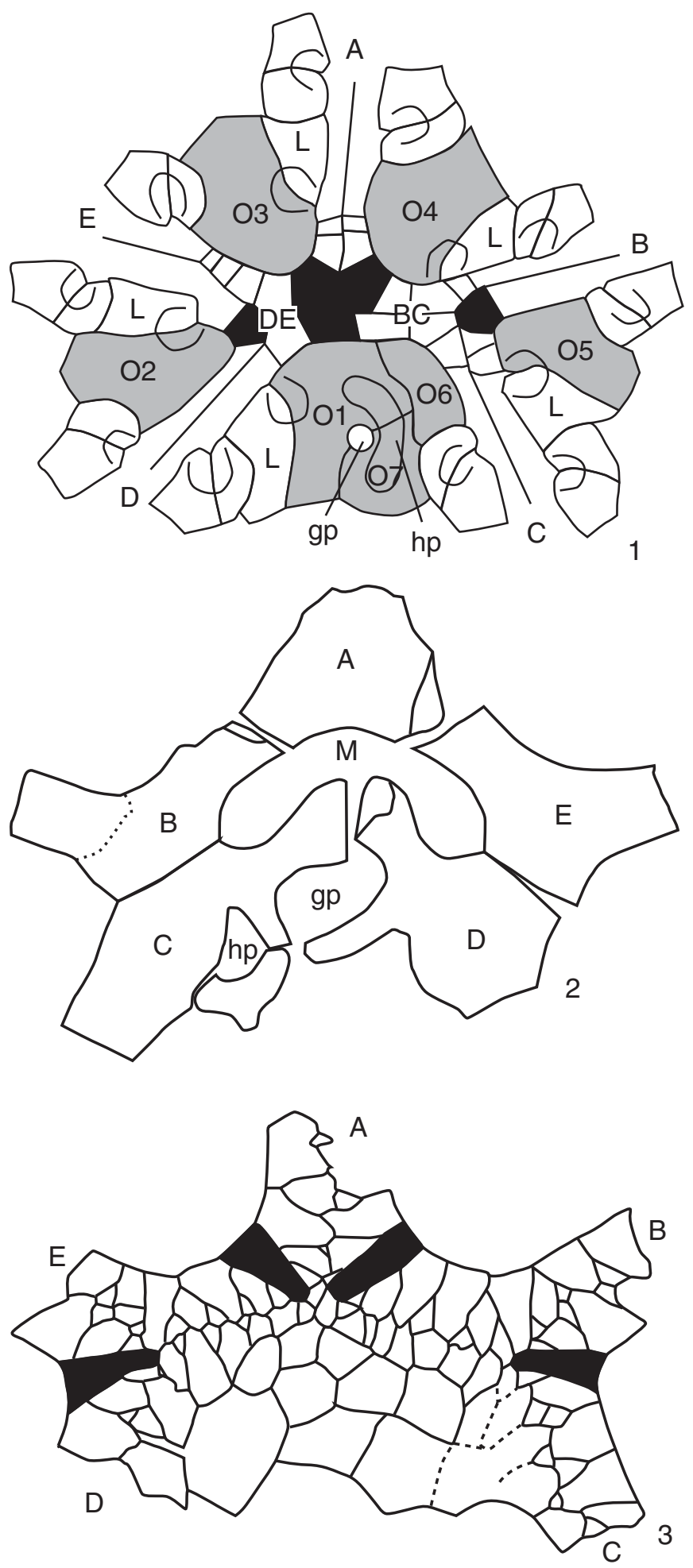

Figure 1. General plating of the ambulacral system in echinoderms. (1) Summit view of the glyptocystitoid Lepadocystis moorei Meek, 1871 UC 57349 showing interradial oral plates with light shading $(\mathrm{O} 1-\mathrm{O} 7)$ framing the five ambulacra (A-E). Dark shading indicates the primary peristomial cover plates. Note the broad exposure of the floor plates bearing brachiole facets. (2) Internal view of the mouth frame of the discocystinid edrioasteroid Hypsiclavus huntsvillensis Sumrall, 1996 UK 116016 showing radially positioned oral frame plates. (3) Exterior view of the oral area of Hypsiclavus guensburgi Sumrall, 1996 1770TX2 showing the primary peristomial cover plates (PPCPs) with dark shading. Note the lack of exposure of either the oral frame plates or adradial floor plate set. $g p=$ gonopore; $\mathrm{hp}=$ hydropore; $\mathrm{m}=$ mouth. (1) Modified from Sumrall (2008); (2) modified from Sumrall and Parsley (2003); (3) modified from Sumrall (1996).
Two fundamentally different plate series are incorporated into the oral area and ambulacral system of pentaradial echinoderms (Kammer et al., 2013). The first is the oral frame plates bordering the peristome and the adradial ambulacral floor plate series (peristomial border type B of Kammer et al., 2013). The oral frame plates are radial in position and form the primary peristomial border as they lie proximally to the oral plates when both series are present (Fig. 1.2). They are designated A-E after the ambulacrum they support (Sumrall and Parsley, 2003). The adradial floor plates are expressed as either uniserial or biserial. Oral frame plates and adradial floor plates are internal in all specimens known, concealed from external view along the edges of the ambulacral system and peristome by interambulacral plating of the extraxial skeleton. Oral frame plates and floor plates form the food groove of most edrioasteroid-grade and some early eocrinoid-grade taxa (Fig. 1.2, 1.3).

The second series of ambulacral elements are the oral plates and the abradial floor plates (peristomial border type A of Kammer et al., 2013). Oral plates lie interradially, forming the peristomial opening, and bear the food groove proximally along their adjacent sutures. They are designated $\mathrm{O} 1-\mathrm{O} 7$, as illustrated in Figure 1.1 with the $\mathrm{CD}$ interradius bearing three plates: O1 and $\mathrm{O} 6$ typically form the edge of the peristomial border, and $\mathrm{O} 7$ is associated with the hydropore and gonopore openings. The abradial floor plates form the food groove distally in most taxa and are either biserial or uniserial. They are broadly exposed externally and often bear facets for brachioles. This plate series forms the axial skeleton found in many derived blastozoans and crinoids.

\section{Materials}

Repositories and institutional abbreviations.-All studied specimens were from museum collections including University of Iowa (SUI); Field Museum of Natural History (FMNH UC); Texas Memorial Museum (TX); Museum of comparative Zoology (MCZ); National Museum of Natural History (USNM); Cincinnati Museum Center (CMCIP); University of Kentucky (UK); Guizhou University (GM and GTBM); the Palaeontological Institute, Russian Academy of Sciences (PIN); University of Michigan Museum of Paleontology (UMMP); and Faculté des Sciences et Techniques Guéliz, Université Cadi Ayyad (FSTG).

\section{The ambulacral system of Kailidiscus as a model}

The middle Cambrian Kailidiscus chinensis Zhao et al., 2010 is an early edrioasteroid-grade echinoderm that shows numerous morphological features in common with other early pentaradiate echinoderms (Zhao et al., 2010). This taxon is extremely well known because specimens are preserved as both external and internal molds that show the nature of the ambulacral system in detail. Its unusual morphologies have informed many ideas concerning the evolution of edrioasteroids and stemmed echinoderms of the pentaradial clade (Sumrall and Zamora, 2011; Kammer et al., 2013).

The mouth frame and ambulacral system of Kailidiscus chinensis provide a reasonable model for the plesiomorphic condition of pentaradiate Echinodermata. Evidence for this 
comes from its early stratigraphic position, the hydropore and gonopore openings not being incorporated into the plating of the ambulacral system, the complex system of adradial and abradial ambulacral floor plates, and the multitiered cover plates (Zhao et al., 2010). Vestiges of each of these characters can be seen in more derived pentaradiate taxa, though it is the least clear in Eleutherozoa, where subsequent character evolution erased most of the data from the mouth frame.

In Kailidiscus, the mouth frame is bordered by two plate series-the precursor plates to the oral frame plates and interradially positioned oral plates (termed integrated interradial plates in Zhao et al., 2010). The precursor oral frame plates are multielemental and form a continuous series with the adradial floor plate system (Fig. 2.1, 2.2). These plates are proximal to the oral plates and form the edge of the peristomial opening. The oral plates lie interradially, immediately distal to the precursor oral frame plates. They are broadly exposed on the thecal exterior, as in nearly all oral-plate-bearing taxa. Furthermore, they bear podial pores along their proximal sutures with the precursor oral frame plates and form a continuous series with the abradial floor plate system both positionally and morphologically (Fig. 2.1). Oral plates $\mathrm{O} 1$ and $\mathrm{O} 6$ are clearly present in the $\mathrm{CD}$ interray; $\mathrm{O} 7$ is possibly present, though this is somewhat unclear in the available material (Fig. 2.2).

The floor plate system of Kailidiscus is quadruserial, bearing an adradial set of floor plates along the ambulacral midline that is bordered by an abradial set of floor plates to the sides (Zhao et al., 2010) (Fig. 2.1, 2.2). Both sets of floor plates contribute to the wide food groove and bear podial pores. The adradial floor plate set meets along the midline biserially and bears two abradially positioned prongs that contact each of two adjacent abradial floor plates. These prongs form the edges of each of three podial pores - two adradial pores that are laterally positioned and one abradial pore that is medially positioned (Fig. 2.1). These plates are fully internal and cannot be seen externally on the theca (Fig. 2.2) except where they wrap around the proximal edge of the orals. The abradial floor plate set lies abradially to the adradial floor plates extending along both lateral margins. These plates show a 1:1 correspondence with the adradial floor plate set. Abradial floor plates bear two prongs extending adradially, articulating to similar prongs on the adradial floor plates forming the border of three pores-two abradial pores laterally and one adradial pore medially (Fig. 2.1). The abradial margin of the abradial floor plates is broadly expressed externally along the ambulacral margin (Fig. 2.2). The cover plates on Kailidiscus are unusual and similar to other Cambrian taxa such as helicoplacoids and cinctans (Zhao et al., 2010, figs. 6, 8). They are broadly generalized and bear several tiers of plates that decrease in size medially though in repeating cycles. No PPCPs are differentiated or recognizable in this taxon.

Discussion.-Two separate pathways are seen in the evolution of pentaradiate echinoderms with respect to the axial skeleton. The first centers on the oral frame plates and adradial floor plates (Type B peristomial borders of Kammer et al., 2013). This includes some Cambrian eocrinoid-grade echinoderms and some derived edrioasteroids. From the thecal interior, this morphotype is recognized by the radial position of the peristomial border plates. From the exterior, it is recognized by a lack of broad expression of peristomial border plates interradially and the lack of expression of the floor plates along the edges of the ambulacra.

The second pathway centers on the oral plates and the abradial floor plate series. This includes derived blastozoans and crinoids (Type A peristomial borders of Kammer et al., 2013). This morphotype is recognized internally by the interradial positioning of the peristomial bordering plates. From the exterior, it is recognized by the broad expression of the interradial peristomial bordering plates and the broad expression of the floor plate bodies along the edges of the ambulacra.

Plesiomorphic edrioasteroids.-Edrioasteroids are a paraphyletic assemblage of globular to discoidal echinoderms that have recumbent ambulacra incorporated into the body wall and lack free brachioles or ambulacral extensions above the theca. Many of the Cambrian forms are difficult to interpret because the bottom surface of the theca is plated, covering information about the mouth frame and floor plates. Some taxa such as Cambraster and Stromatocystites have large interradial oral plates much like Kailidiscus (Zamora et al., 2013b,

\footnotetext{
Figure 2. Colorized photographs showing the distribution of plate types on pentaradiate echinoderms. (1, 2) Internal and external views of the Kailidiscus chinensis paratype GM2103, showing the plating of the peristomial border and ambulacral floor plate system. Red plates are the oral plates; green plates are the abradial floor plates; light blue plates are the adradial floor plates; purple plates are the precursor oral frame plates. Note that in the distal ambulacra, only the abradial floor plates can be seen outside the food groove but are visible because the cover plates in yellow are taphonomically stripped from most of the specimen. (3) Interior view of the eocrinoid-grade echinoderm Lepidocystis wanneri Foerste, 1938 MCZ628 showing radial oral frame plates in purple and adradial floor plates in light blue. (4) The oral area of Lepidocystis wanneri GTBM95265 showing radial oral frame plates in purple. Brachioles mount at the ambulacral tips. (5) Interior view of the sorophinid Anedriophus moroccoensis Sumrall and Zamora, 2011, FSTG/AA-BCBb-OI-25. Radial oral frame plates in purple lead to uniserial adradial floor plates in light blue. Primary peristomial cover plates in blue and cover plates with podial basins and intrambulacral canals in yellow cover the food groove. (6) The parablastoid Eurekablastus ninemilensis Sprinkle and Sumrall, 2008 1781TX5 showing abradial floor plates in green and oral plates in red. Primary peristomial cover plates in blue and ambulacral cover plates in yellow cover the ambulacra. (7, 8) Exterior CMCIP 40480 and interior CMCIP 40478 view of Edriophus levis. Oral plates in red and abradial floor plates in green are visible from exterior while oral frame plates in purple can only be seen from the interior. Primary peristomial cover plates in blue and ambulacral cover plates in yellow cover the ambulacra. (9) Detail of the diploporitan Eumorphocystis multiporata Branson and Peck, 1940 SUI97599 showing the construction of the ambulacrum. Abradial floor plates in green are in contact with extraxial plates in pink arising from single 'radial plate' in black- note filler plates in light yellow and large lumen proximally. Cover plates and brachioles are in dark yellow. (10) Lateral view of Lipsanocystis rugosus Stumm, 1955 UMMP 31432 showing double biserial outer floor plates in green and light green. Oral plates are in red. (11) Summit view of Eumorphocystis multiporata SUI97598 showing abradial floor plates in green and oral plates in red. Primary peristomial cover plates in blue and ambulacral cover plates in yellow cover the ambulacra. (12, 13) Oral views of the eocrinoid grade echinoderm Rhopalocystis destombesi Ubaghs, 1963 without PMO A29122 and with PMO A29124 cover plates. Oral plates in red lead to abradial floor plates in green. Primary peristomial cover plates in blue and ambulacral cover plates in yellow cover the ambulacra. (14) The crinoid Neoplatycrinus dilatatus Wanner, 1916 SUI 134856 showing greatly enlarged primary peristomial cover plates in blue and ambulacral cover plates in yellow. (15) The crinoid Collicrinus yandelli Owen and Shumard, 1850 USNM S1337 showing greatly enlarged primary peristomial cover plates in blue and ambulacral cover plates in yellow. (16) The crinoid Nuxocrinus crassus Whiteaves, 1887 USNM 305473 showing greatly enlarged primary peristomial cover plates in blue and ambulacral cover plates in yellow. Scale bars $=5 \mathrm{~mm}$. (1-5, 7, 8, 11-16) Modified from Kammer et al. (2013); (6, 9, 10) new.
} 


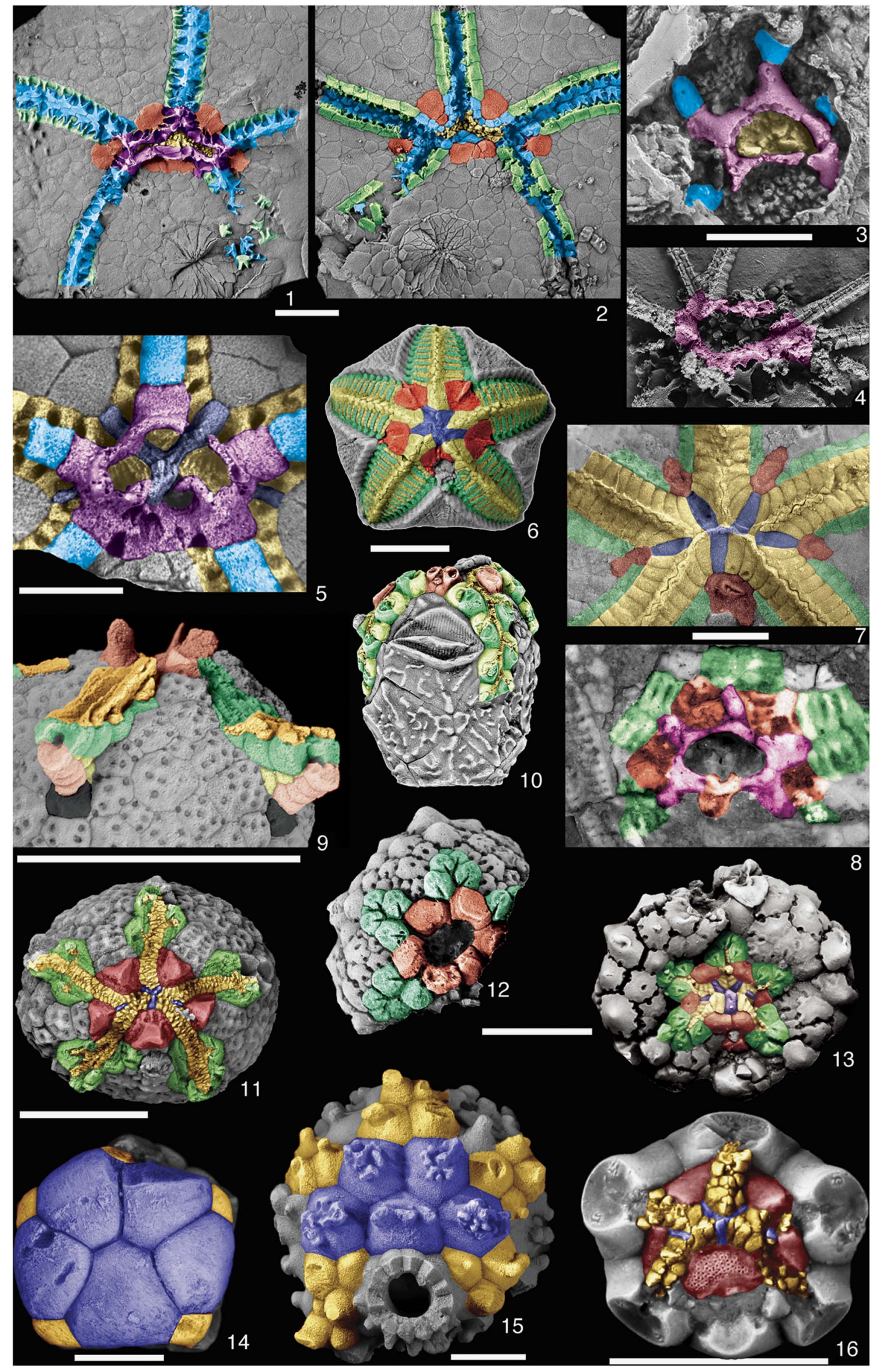


2015), but the presence of oral frame plates and the nature of the floor plates cannot be clearly seen.

Edrioasterine edrioasteroids appear to have a combination of oral frame plates, oral plates, and abradial floor plates. The presence of both oral plates and oral frame plates is confirmed from a few exposed oral area interiors seen on specimens of Edriophus levis Bather, 1914 (see Bell, 1976; Kammer et al., 2013). The oral frame plates form the peristomial opening and preclude the oral plates from contact with the peristome (Fig. 2.8). Distally, they articulate to the proximal-most abradial ambulacral floor plates, terminating in a point along the midline. The interradial oral plates are the only peristomial bordering plates seen from the exterior of the theca (Fig. 2.7). Apparent facets on oral plates of edrioblastoids suggest the presence of oral frame plates, but none have been directly observed because of the nature of the preservation (Kammer et al., 2013). The abradial floor plates are widely exposed externally and show nearly identical morphologies to those seen of the abradial floor plate series of Kailidiscus (Fig. 2.2, 2.7), and they bear sutural pores for podia (Fig. 2.8). Furthermore, they are in line with the oral plate series as in Kailidiscus, strongly suggesting that these are the abradial floor plates.

In pyrgocystid isorophid edrioasteroids, the oral frame is constructed only by interradial oral frame plates (Sumrall and Zamora, 2011). The floor plate system is plated with two sets of floor plates - uniserial and imbricating adradial floor plates and biserial and laterally positioned abradial floor plates (Sumrall and Zamora, 2011). The abradial floor plates bear sutural pores, presumably for podia, and have the ambulacral cover plates mounted upon them. Later isorophinid edrioasteroids lost the abradial floor plate series (see the following). This results in an axial skeleton composed of interradial oral frame plates articulating to uniserial adradial floor plates that are entirely internal. These structures can only be seen from specimens exposing the interior of the theca or reconstructed from isolated thecal plates (Sumrall and Parsley, 2003).

\section{Oral-frame-plate-/adradial-floor-plate-bearing taxa}

Several Cambrian eocrinoid-grade taxa and isorophinid edrioasteroids share an axial skeleton composed of radial oral frame plates and adradial floor plates as a basic constructional design, though through different lineages. Unfortunately, these plates are all internal and difficult to observe in taxa unless preserved with a broken interior view or similar preservation. Consequently, this is much more poorly understood than oral plate/abradial floor plate designs discussed in the following. These structures are also present in only a few taxa, and therefore, the known diversity of these structures is limited in comparison to systems based on oral plates and abradial floor plates.

In the middle Cambrian eocrinoid-grade echinoderm Lepidocystis, the oral area can be observed from both the interior and exterior surfaces (Sprinkle, 1973). The exterior surface is poorly documented, but the five ambulacra radiate in 2-1-2 symmetry from a centrally located peristome covered by an oral cone. Where interradial oral plates would be positioned, there are only small platelets of the interambulacral plating documenting the absence of these plates. The floor plates (thought to represent adradial floor plates) are poorly exposed on the oral surface except where brachioles mount, but details are lacking because of the disrupted nature of these specimens. Similar construction in the better-preserved Kinzercystis shows epispires right up to the food groove (Sprinkle, 1973, pl. 4.1), showing that these plates are not broadly expressed as they typically are in taxa bearing the abradial floor plates. Brachioles arise alternately from these floor plates mounted adjacent to the food grooves rather than alongside ambulacra (Sprinkle, 1973).

Exposed interior views of two specimens show the nature of peristomial border and floor plates (Sprinkle, 1973; Kammer et al., 2013). The peristomial border bears a frame of radially positioned oral frame plates bordering bean-shaped peristomial opening (Fig. 2.3). Each of the five main plates leads to an ambulacrum, and the CD side apparently has an extra plate of unknown origin. Again, the absence of oral plates can be clearly shown by the presence of small interambulacral plates filling the areas between the oral frame plates and adradial floor plates in the proximal-most interambulacral areas (Fig. 2.3). Although poorly seen, the floor plates appear to be biserial because of the presence of angled sutures (Fig. 2.3) and show a narrow expression in the interambulacral areas.

Gogiids are less well known, but there is evidence that these too have oral frame plates as peristomial bordering plates. Specimens of the gogiid Sinoeocrinus (Parsley and Zhao, 2006) from the middle Cambrian of China have a reduced oral surface in which the peristome is bordered by radially positioned oral frame plates (Fig. 2.4) that give rise to terminal brachioles (Kammer et al., 2013). In some larger specimens, there are groups of terminal brachioles, but how these structures are related to floor plates is presently unknown. Other gogiids with preserved oral surfaces do not expose obvious floor plates externally, and it is assumed that this is evidence that they are internal and likely the adradial set.

Isorophinid edrioasteroids show a second example of the axial skeleton being formed from oral frame plates and adradial floor plates. More plesiomorphic forms such as pyrgocystids bear only oral frame plates around the peristome but retain both adradial and abradial floor plates in the ambulacra (Sumrall and Zamora, 2011, fig. 14). In isorophinids, the abradial floor plate set is lost, leaving only the adradial set to form the food groove (Fig. 2.5). The oral frame plates and the adradial floor plates are strictly internal features and only visible from fortuitous interior views of the oral surface (Fig. 2.5). A bean-shaped peristome is bordered by five radially positioned oral frame plates of which $\mathrm{C}$ and D are extended into the CD interray (Fig. 1.2) associated with the hydropore and gonopore (Sumrall and Parsley, 2003). The distal ends of the oral frame plates become U-shaped and align with U-shaped, uniserial floor plates that floor the rest of the ambulacral length (Fig. 2.5). Floor plates can be either adjacently or imbricately sutured.

Cover plates mount atop the oral frame plates and adradial floor plates, roofing the food groove. In many taxa, there are pores along the hinge line passing between the cover plates and the floor plates, possibly forming podial basins and passageways for podia (Fig. 2.5). In these taxa, the cover plates are long with broad intrathecal extensions. In more-derived taxa, the cover plates lack these extensions and apparently lack the pores as well. 


\section{Oral-plate-/abradial-floor-plate-bearing taxa}

Glyptocystitoid rhombiferans as a model.-A common expression of the UEH model is found in glyptocystitoid rhombiferans and forms the archetype for oral-plate-bearing taxa (Fig. 1.1). In glyptocystitoids, seven oral plates are positioned interradially around the peristome with $\mathrm{O} 1, \mathrm{O}$, and $\mathrm{O} 7$ lying in the $\mathrm{CD}$ interray and $\mathrm{O} 2-\mathrm{O} 5$ positioned around the peristomial opening clockwise from O1. The 2-1-2 ambulacral symmetry of Sprinkle (1973) is well developed with the shared ambulacra positioned on the O4/O6 and O3/O1 sutures (Fig. 3.1). This results in $\mathrm{O} 2$ and O5 being precluded from the peristomial opening by these sutures. The PPCPs are small and separated, with plates 1, 3, and 4 marking the insertion point of the $\mathrm{A}$ ambulacrum (when present) and plates 2 and 5 marking the bifurcation points of the lateral B, C, D, and E ambulacra (Fig. 1.1). Double biserial abradial floor plates extend from the oral plates beginning on the left (Fig. 2.10). The ambulacral grooves are covered by undifferentiated cover plates.

Remarks. - The oral system of glyptocystitoids is straightforward. The floor plates are interpreted as the abradial floor plate series because they are broadly exposed along the margins of the ambulacral system and bear brachiole facets along the primary/ secondary sutures of the floor plate bodies. Similar morphologies are seen in the other derived blastozoans and can be interpreted as variations on this theme and easily reconciled with the glyptocystitoid model (Fig. 3). Following are discussions of variation in expression of the oral plate and floor plate systems seen throughout this large echinoderm clade.

There is considerable variation among derived blastozoans with respect to the fate of the lateral oral plates $\mathrm{O} 2$ and $\mathrm{O}$. Some taxa, such as Rhopalocystis, show a simplification of the 2-1-2 symmetry by bearing shorter shared ambulacra (Sumrall and Wray, 2007; Kammer et al., 2013) (Fig. 2.12, 2.13). Such taxa do not bear sutures between $\mathrm{O} 4 / \mathrm{O} 6$ and $\mathrm{O} 3 / \mathrm{O} 1$ that preclude the lateral oral plates from the peristomial border as in Kammer et al.'s (2013) peristomial border A2. Instead, they have $\mathrm{O} 2$ and $\mathrm{O} 5$ contact with the peristomial border forming Kammer et al.'s (2013) peristomial border A3. This type of shared ambulacral reduction (pseudo-five-fold symmetry of Sumrall and Wray, 2007) is common in derived stemmed echinoderms, and variations are seen in coronates (Fig. 3.7), blastoids (Fig. 3.8), plesiomorphic crinoids (Fig. 3.9), and several of the diploporitan clades (Figs. 2.11, 3.11).

Blastoids and coronates. - The oral plate systems of blastoids (Fig. 3.8) and coronates (Fig. 3.7) are similar owing to their close phylogenetic relationship (Brett et al., 1983; Donovan and Paul, 1985). In these taxa, oral plates are the deltoids whose adjacent sutures form the proximal-most food grooves (Sumrall and Waters, 2012). In many blastoids, the orals bear large deltoid bodies that extend distally down the theca, becoming important constructional elements of the thecal wall. The ambulacra share the peristome more or less evenly, and consequently, these taxa show almost no hint of 2-1-2 symmetry except in the configuration of the primary peristomial cover plates (Fig. 3.7) and a slightly wider than high peristomial opening in most blastoids (Fig. 3.8). The CD interray bears two dominate plates, likely $\mathrm{O} 1$ and $\mathrm{O} 7$, and in blastoids may include accessory plates (cryptodeltoids, etc.). These plates show a variety of relationships to the periproct and spiracles (exit pores of the respiratory system in many blastoid groups), forming the basis for present classifications of blastoids (but see Bauer et al., 2017).

Hemicosmitoids.-In the hemicosmitoid Hemicosmites, the oral area is greatly simplified by paedomorphic ambulacral reduction to include only the A, shared $\mathrm{BC}$, and shared $\mathrm{DE}$ ambulacra (Sumrall and Wray, 2007; Sumrall, 2008). The lateral oral plates $\mathrm{O} 2$ and $\mathrm{O} 5$ do not develop in this taxon, associated with the failure of the shared ambulacra to bifurcate (Fig. 3.6). Enlarged oral plates $\mathrm{O} 7, \mathrm{O} 3$, and $\mathrm{O} 4$ occupy the interradial areas of the remaining three ambulacra. Plates O1 and O6 (wedge plates of Bockelie, 1979, in part) are extremely small and lie between O7 and the oral area (Fig. 3.6). The first left brachiole facets lie on the sutures between the first secondary floor plates (wedge plates of Bockelie, 1979, in part) and the remaining oral plates (Sumrall, 2008). Paired, likely fused, floor plates positioned between the oral plates form facets for erect, brachiole-bearing ambulacra of the distal ambulacra (Sprinkle, 1975) (see the following).

Diploporitans.-The diploporitan Protocrinites (Fig. 3.3) shows an oral plate arrangement that is consistent with the glyptocystitoid model. Seven interradial oral plates are present, with $\mathrm{O} 2$ and $\mathrm{O} 5$ being precluded from the peristome by the $\mathrm{BC}$ and DE shared ambulacral grooves. As the result, only $\mathrm{O} 1, \mathrm{O} 3$, $\mathrm{O} 4$, and $\mathrm{O} 6$ form the peristomial opening. The hydropore and gonopore are positioned in the $\mathrm{CD}$ oral plate complex.

Some diploporitan clades, such as Glyptosphaerites and Eucystis, show a $36^{\circ}$ clockwise rotation of the oral plates with respect to the ambulacra (Fig. 3.5). Here, the main food grooves lie atop the oral plates (repeatedly branching in Eucystis), rather than along the adjacent sutures, and extend distally irregularly down the theca. The oral plates are diagnosable despite their radial position because they retain the plesiomorphic seven-plate oral configuration condition (Fig. 3.5). Plates O1, O6, and O7 are positioned in the $\mathrm{CD}$ interradius as evidenced by $2-1-2$ ambulacral symmetry, the primary peristomial cover plate configuration, and the positions of the hydropore, gonopore, and periproct (Fig. 3.5). The PPCPs, however, retain the plesiomorphic interradial position.

Holocystitid diploporitans are modified from the plesiomorphic condition by the addition of a differentiated, open facetal circlet positioned distally to the oral circlet (Fig. 3.11). This has led to considerable confusion of homology in the clade, but all taxa seem to retain the plesiomorphic seven oral plate condition (see Sheffield and Sumrall, 2015; 2017). Generally, extremely short food grooves extend along oral plate sutures epithecally to large appendage facets mounted on differentiated thecal plates (facetals). Here, the oral plates tend to be rather small, and food grooves are confined to their sutures or adjacent plate surfaces. This same pattern is seen in nearly all taxa, but the facetal count may be reduced in Pustulocystis and there may be additional oral plates in Brightonicystis (Paul 1971; 

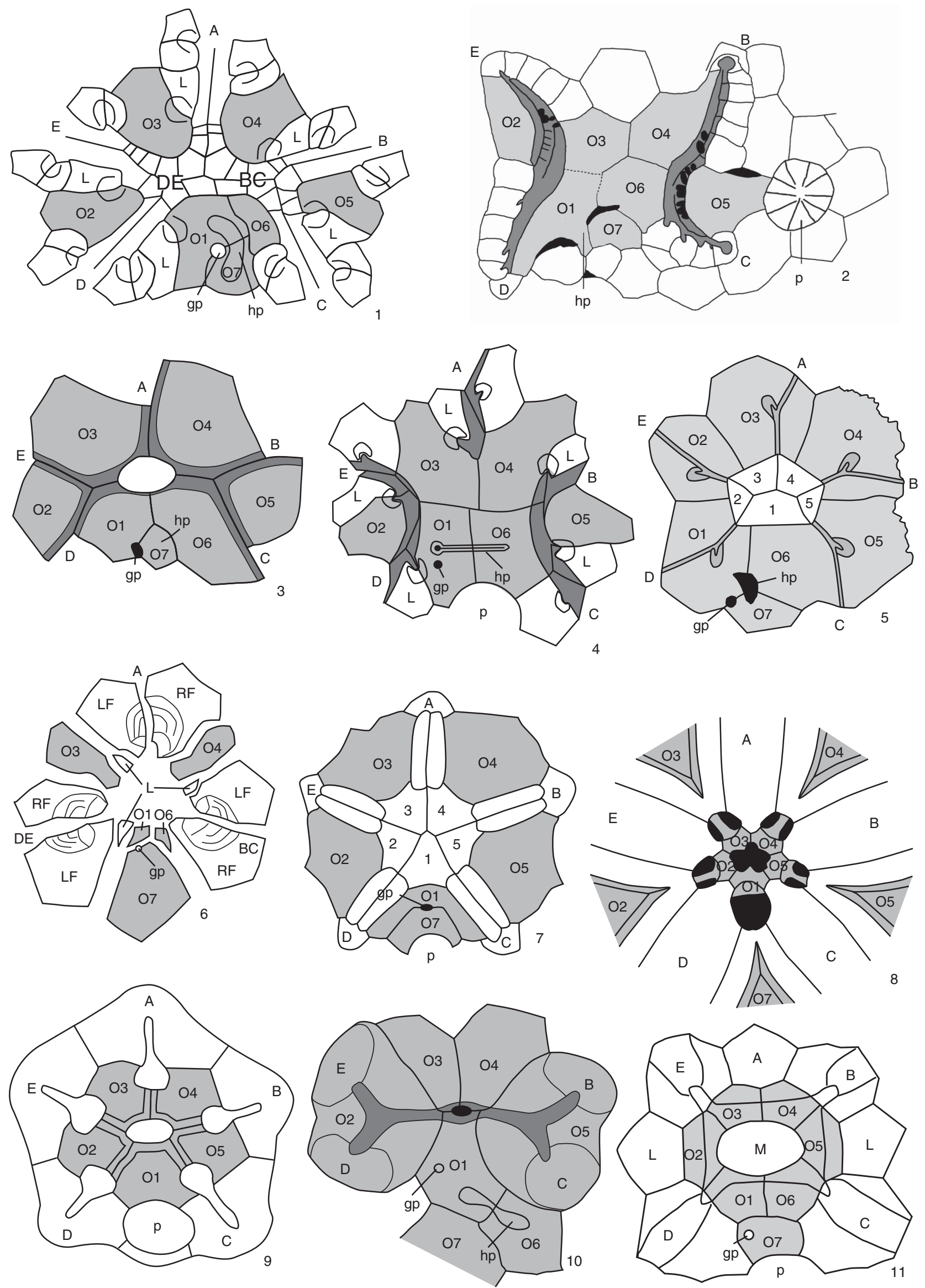
Frest et al., 2011), though these genera have yet to be restudied (Sheffield and Sumrall, 2017).

The diploporitan Tristomiacystis bears five ambulacra that enter the esophagus via three mouth openings-one for the A ambulacrum and two for each of the shared ambulacra (Fig. 3.4) (Sumrall et al., 2009). The oral plates are enlarged and extend over the centrally located oral area; the PPCPs and shared cover plates are not present. The hydropore and gonopore are associated with $\mathrm{O} 1$ and $\mathrm{O} 6$, and plate $\mathrm{O} 7$ is absent (Sumrall et al., 2009). Thecal-wall-forming abradial floor plates that bear diplopores extend down the theca biserially, bearing brachiole facets (Fig. 3.4).

Paracrinoids.-Paracrinoids show considerable variation in oral plate arrangement, but they generally retain the plesiomorphic seven oral plate configuration. Columbocystis retains the plesiomorphic condition with large appendage facets mounted along the oral plate sutures (Kammer et al., 2013). The nature of the appendages is at present unknown. In Implicaticystis, the A ambulacrum is absent, resulting in long shared ambulacra that bifurcate to the distal B-E ambulacra on the lateral orals, $\mathrm{O} 2$ and O5 (Frest and Strimple, 1982). These plates each have two large facets for free appendages (Fig. 3.10). Because of their great enlargement, $\mathrm{O} 6$ and $\mathrm{O} 7$ are precluded from the peristomial border, resulting in a three-plate peristomial border- $\mathrm{O} 1, \mathrm{O} 3$, and $\mathrm{O} 4$ (Fig. 3.10).

In Canadocystis, the oral area is somewhat confused by the placement of recumbent ambulacral floor plates over the lateral portions of the theca (Parsley and Mintz, 1975, pl. 11, fig. 14). The CD interray is plated with $\mathrm{O} 1$ and $\mathrm{O} 6$ forming the peristomial border with $\mathrm{O} 7$ distal to them, and these plates are associated with the hydropore and gonopore. While the A ambulacrum is absent, the suture for $\mathrm{O} 3$ and $\mathrm{O} 4$ is present, and these plates form the anterior edge of the peristome. It appears that $\mathrm{O} 2$ and $\mathrm{O} 5$ are also present, but these plates are nearly covered by the placement of the recumbent ambulacra across their exterior surface.

The oral plates of Bistomiacystis (Fig. 3.2) have been greatly modified such that two peristomial openings that connect internally to a single esophagus are present (Sprinkle and Parsley, 1982). The B and C ambulacra unite on the right side of the oral area and enter on peristome; the $\mathrm{E}$ and $\mathrm{D}$ ambulacra unite to form a second peristome on the left. The A ambulacrum is absent via paedomorphic ambulacral reduction (Sumrall and Wray, 2007). Plates O1, O3, O4, and O6 roof over the centrally located common peristome that must be present where the two mouths meet internally. The hydropore and gonopore are associated with $\mathrm{O} 1, \mathrm{O}$, and $\mathrm{O} 7$ in the $\mathrm{CD}$ interray. Elongated $\mathrm{O} 1, \mathrm{O} 2, \mathrm{O} 4$, and $\mathrm{O} 5$ form the food groove where they suture with left side floor plates of the ambulacral system (Sumrall and Deline, 2009).
Crinoids.-Crinoids show peristomial configurations that transition between a standard oral plate-dominated summit configuration (Figs. 2.16, 3.9), a tegmen with recognizable PPCPs and CPs (Fig. 2.14, 2.15), and a plated-over tegmen with unrecognizable skeletal elements (Ausich and Kammer, 2016). Numerous taxa bear an oral plate dominated summit such as Nuxocrinus (Fig. 2.16). Here, large, interradially positioned oral plates occupy the five interradial fields. The CD interray bears a single oral plate that appears to be $\mathrm{O} 1$ - a condition that is somewhat unusual for oral plate bearing echinoderms (Kammer et al., 2013). Where known, all five ambulacra enter the peristome via food grooves that lie atop the sutures between the five oral plates (Fig. 3.9). The oral plates end at large pores where coelomic canals pierce the summit at the aboral edge of the oral plates (Fig. 3.9). The oral area and proximal ambulacra are roofed by poorly differentiated primary peristomial cover plates and ambulacral cover plates (Fig. 2.16). These typically are not preserved over the coelomic canals as there are generally no skeletal floor plates to support them postmortem.

Other crinoids, such as monobathrid camertes, have no visible oral plates on the thecal exterior, and these plates are either strictly internal or uncalcified (Kammer et al., 2013). Instead, the summit is covered by a tegmen, with many of the plates derived from the peristomial and ambulacral cover plate systems and filler plates (Fig. 2.14, 2.15). In many taxa, the PPCPs lie centrally and articulate with the 2-1-2 symmetrical arrangement (Fig. 2.15). Cover plates extend radially toward the arms in a biserial arrangement. Spaces between the arms are filled with tegmen-filling plates of uncertain origin. More derived taxa, such as Neoplatycrinus, greatly enlarge the PPCPs that dominate the tegmen (Fig. 2.14).

Other taxa such as diplobathrid camerates and protocrinoids (where known) have the plates of the tegmen undifferentiated (Guensburg and Sprinkle, 2010; Ausich and Kammer, 2016). This derived condition results in a loss of distinction between elements of the cover plate system and the filler plates of the tegmen. It seems likely that this condition is gained ontogenetically, but this has not been confirmed pending ontogenetic studies. Ausich and Kammer (2016) provide a thorough review of tegmens and their evolutionary significance that is beyond the scope of this manuscript.

\section{Abradial ambulacral floor plates}

One of the defining characters of the oral-plate-bearing blastozoan clade is the presence of well-developed abradial floor plates and the apparent absence of adradial floor plates, associated with the presence of oral plates and the absence of the oral frame plates. This seems reasonable because in Kailidiscus the abradial floor plates and oral plates form a continuous plate series whereas the oral frame plate precursors form a continuous plate series with the adradial floor plates (Fig. 2.1, 2.2).

Figure 3. Peristomial bordering plate configurations across derived blastozoans. (1) The glyptocystitoid Lepadocystis; (2) the paracrinoid Bistomiacystis; (3) the diploporitan Protocrinites; (4) the diploporitan Tristomiacystis; (5) the diploporitan Glyptosphaerites; (6) the hemicosmitoid Hemicosmites; (7) the coronate Stephanocrinus; (8) the blastoid Pentremites; (9) the crinoid Hybocrinus; (10) the paracrinoid Implicaticystis; (11) the diploporitan Paulicystis. A-E = ambulacral designations; O1-O7 = oral plates (shaded); $1-5=$ primary peristomial cover plates; $\mathrm{L}=$ first left floor plate; hp = hydropore; gp = gonopore; $\mathrm{p}=$ periproct. $(\mathbf{1}, \mathbf{3 , 6}, \mathbf{9})$ after Sumrall (2008); (2) after Sumrall and Deline (2009); (4) after Sumrall et al. (2009); (7, 8) after Sumrall and Waters (2012); (10) after Frest and Strimple (1982); (11) after Sheffield and Sumrall (2015). 
In derived oral-plate-bearing blastozoans, evidence that this clade bears the abradial floor plates comes largely from the nature of the expression of these plates. In Kailidiscus and Edriophus (Fig. 2.2, 2.7), the abradial floor plates are biserial and are widely expressed on the thecal exterior, perradially to the food groove. Ambulacral cover plates cover the food groove hiding the perradial suture from exterior view. A similar situation exists among derived blastozoans. Here, widely expressed biserial, or in some cases double biserial, floor plates arise from the oral plates with a relatively narrow food groove and in most cases widely externally expressed floor plate bodies abradial to the food groove (Fig. 2.10-2.12). This floor plate body typically bears facets for brachioles in a number of different configurations with respect to the plate sutures (Sumrall, 1997).

Variation in floor plate expression.-Rhopalocystis (Fig. 2.12, 2.13) shows a typical configuration for the abradial floor plates of an oral-plate-bearing blastozoan. Abradial floor plates extend from the sutures of the oral plate series with the first plate on the left (Fig. 2.12), and these plates structurally form the thecal wall. The narrow primary food groove lies along the perradial suture between right and left side floor plates. Cover plates cover the food groove leaving the broad floor plate bodies exposed abradially to the food groove (Fig. 2.13). Side food grooves arise from the primary food grooves, leading to brachiole facets centered on each plate. Other abradial floor plate systems are variations on this general pattern with floor plates becoming erect, or positioned epithecally upon the theca, and brachioles arising from the floor plates in different positions. In some taxa, the floor plates are lost altogether.

In many taxa, such as Tristomiacystis and early cheirocrinid glyptocystitoids, the abradial floor plates are positioned as in Rhopalocystis, with biserial or double biserial floor plates forming the thecal wall. In the parablastoid Eurekablastus (Fig. 2.6), plating is similar, except that the side food groove lies along the floor plate sutures and distally extends onto brachiole facets that lie on the center of the abradial edge of the floor plates (Sprinkle and Sumrall, 2008). In this case, there is a 1:1 correspondence of floor plates to cover plates over the main food groove-a situation argued to be unique to crinoids and edrioasteroids (Guensburg et al., 2016). Taxa with this configuration can also house respiratory structures in the floor plate bodies as seen with the floor-plate-borne diplopores of Dactylocystis and Tristomiacystis (Sumrall et al., 2009).

Other clades, including the glyptocystitoids Glytocystites and Lipsanocystis (Fig. 2.10) and many paracrinoids, modified this pattern by having the oral plates sutured to the thecal plates and placing the abradial floor plates atop the thecal plates. These epithecal floor plates typically form scars on the surfaces of the thecal plates that are evident when the floor plates become disassociated taphonomically. In paracrinoids such as Canadocystis (Parsley and Mintz, 1975, pl. 11, fig. 14), the floor plates are heavily sutured to the thecal plates, and these plates remain intact taphonomically, covering the sutures of the oral plates and making them difficult to interpret.

The abradial floor plates of blastoids are also positioned epithecally upon the lancet plate of the theca (Sumrall and Waters, 2012). The ambulacral floor plates (called side plates in blastoid terminology) in most cases form the main food groove along the parradial suture. However, in several taxa-notably Pentremeites - the abradial floor plates are divided along the midline, exposing the underlying lancet plate. In these taxa, the main food groove and proximal portion of the side food grooves lie upon the extraxial skeleton for a short distance before becoming axial again. This situation changes during ontogeny of individual food grooves that form along sutures of adjacent floor plates at the growing tip of the ambulacrum and become overtaken by the distally expanding exposure of the lancet plate.

Still other taxa, notably some diploporitans such as Glyptosphaerites (Fig. 3.5) and Eucystis (Kesling, 1967, fig. 144.2e), extend the ambulacral food grooves without underlying floor plates. In Glyptosphaerites, the oral plates bear food grooves across their surface rather than suturally (Fig. 3.5). The oral plates articulate to the thecal plates, and distally, the narrow food groove extends across the thecal surface without regard to the underlying thecal plate boundaries. At intervals, small side food grooves extend to small brachiole facets. Eucystis is similar except that numerous ambulacral branches occur on the oral plates, which lead to brachiole facets on the oral plates and most proximal thecal plates (Kesling, 1967, fig. 144.2e).

Nonbiserial ambulacral floor plates.-There are two notable variants on the typical biserial plate arrangement of abradial floor plates in oral plate bearing Blastozoa. First, is the uniserial floor plates of paracrinoids. These plates arise only from the left side and bear unusual uniserial brachioles (Parsley and Mintz, 1975). Floor plates typically form the left side of the food groove, and in many taxa the right side of the food groove is formed from enlarged oral plates such that the oral plates articulate to numerous floor plates (Fig. 3.2). In others, the floor plates become highly asymmetrical and occupy both right and left sides of the food groove. These floor plates are often epithecaly sutured to the theca and do not structurally form the thecal wall. In a few notable cases, the floor plates are raised into erect ambulacra as in Implicaticystis (Fig. 3.10) (see the following).

The second notable variant is the double biserial plating found in blastoids, coronates, glyptocystitoids, hemicosmitoids, and perhaps trachelocrinids. In these taxa, brachioles arise along the sutures of paired primary and secondary abradial floor plates (Fig. 2.10). Typically, the primary plate is notably larger than the secondary plates and the side food groove lies along their common suture. These plates can be very large as in glyptocystitoids or very small as in blastoids, where they are called side plates. In coronates and hemicosmitoids, they are formed into erect appendages (see the following) but retain their differentiation in this state. In trachelocrinids, they are also erect but secondary plates occur only every third floor plate, alternating right and left down the length of the erect appendage (Sumrall et al., 1997).

While it is possible that the primary and secondary plates of these clades may correspond to the adradial and abradial plates of the plesiomorphic pentaradial condition, this seems unlikely. First, morphologically, primary and secondary plates in these taxa all have the characteristics of abradial plates with broad exposure along the edge of the food groove. Second, phylogenetic analyses place these taxa well derived within the 
oral-plate-bearing blastozoan clade (Paul and Smith, 1984; Smith, 1984; Paul, 1988; Sumrall, 1997).

Erect ambulacra.-The ambulacral floor plate system of several taxa, including coronates, hemicosmitoids, and trachelocrinids, form erect, brachiole-bearing appendages (Sprinkle, 1975; Brett et al., 1983; Sumrall et al., 1997; Zamora and Smith, 2011; Guensburg et al., 2016). A distinction needs to be made between erect ambulacra that are cored by floor plates and brachioles that are free appendages that arise from floor plates. Lack of clarity in this distinction has arisen in earlier studies (Smith, 1990; Zamora and Smith, 2011). Appendages that can be diagnosed as floor plates are generally biserial and bear brachioles in a similar manner as other brachiole-bearing taxa with recumbent ambulacra. These brachioles are mounted on the floor plates typically with short side food grooves that lead to the facet from which the brachioles arise. Taxa with large erect brachioles such as pleurocystitids, by contrast, bear stout biserial appendages that lack brachioles. Some confusion may exist where terminal brachioles mount on oral plates, but in most cases more than one are present in more mature specimens, and in well-preserved material, floor plates can be seen incorporated into the summit area (Broadhead and Sumrall, 2003).

In many taxa with erect ambulacra, only floor plates, cover plates, and brachioles are incorporated into the raised structures. The plating here is relatively straightforward with biserial, or in some cases double biserial, abradial floor plates forming the main trunk of the appendage without the incorporation of extraxial skeleton. Generally, these appendages do not branch distally as is common among crinoids, though in many hemicosmitoids the ambulacra do branch upon the tegmen of the theca, leading to multiple appendages. Brachioles arise from these erect ambulacra and show a variety of articulating configurations: attachment to plate sutures, centered in individual floor plates, or attachment to pairs of primary and secondary plates (Sumrall, 1997).

For coronates and hemicosmitoids, there are no objective morphological criteria for determining whether the erect floor plates are adradial or abradial. However, phylogenetic criteria strongly suggest that these plates are abradial. Coronates have long been considered closely affiliated with blastoids (Brett et al., 1983; Donovan and Paul, 1985; Bodenbender and Fisher, 2001; Sumrall and Waters, 2012), and hemicosmitoids have been thought to be at least somewhat closely allied with glyptocystitoids (Paul and Smith, 1984; Paul, 1988). These placements are supported by the unusual double biserial floor plates bearing both primary and secondary plates that bear brachioles along their common sutures (Sprinkle, 1975; Brett et al., 1983; Sumrall, 2010; Sumrall and Waters, 2012). As the floor plates of glyptocystitoids and blastoids are consistent with abradial floor plates, it is reasonable to interpret the plates of hemicosmitoids and coronates as abradial as well. The floor plates of trachelocrinids have even less certainty in identification, but based on the presence of oral plates, a holomeric stem and earlier phylogenetic analysis, they would appear to bear abradial floor plates (Sumrall, 1997; Sumrall et al., 1997).

The term 'arm' has typically been used to signify erect appendages in which there are axial and extraxial components to the appendage and a central lumen (Zamora and Smith, 2012; Guensburg et al., 2016). However, this term is not useful as it masks the underlying elemental construction of the appendage. This general pattern of compound erect ambulacra shows three basic constructional groups in which erect floor plates arise from the ambulacral system accompanied by a joined component of extraxial skeleton-Dibrachicystis/Vizcainoia, Eumorphocystis, and Crinoidea. In Dibrachicystis (Zamora and Smith, 2011), the ambulacral food groove lies on a complex arrangement of biserial floor plates and a discontinuous series of extraxial elements positioned along the midline proximally. Although the food groove is relatively large, there is no indication of a skeletally enclosed coelom running the length of the erect appendage, nor is there any indication of brachioles. The construction of Vizcainoia is similar except that the extraxial component is uniserial and continuous along the length of the appendage (Zamora and Smith, 2011).

Whether these appendages represent terminal brachioles or erect distal ambulacra is equivocal pending the discovery of specimens that preserve the oral surface much better. If they are terminal brachioles, these taxa bear unique brachioles that are compound structures bearing axial and extraxial components much like crinoid arms. If they are erect ambulacral floorplate-bearing structures, these taxa bear a construction that is even more similar to crinoids by bearing both axial and extraxial skeleton with a concomitant loss of brachioles along their length.

The ambulacra of Eumorphocystis are complex, showing a combination of recumbent and erect ambulacra (Parsley, 1982). Food grooves on the oral plates extend onto elongate, biserial, abradial floor plates that bear single brachiole facets (Fig. 2.9, 2.11). These extend to the edge of the oral surface, where they join with a uniserial set of extraxial elements arising from a single 'radial plate' on the thecal wall. A few filler plates are present where these two plate series meet (Fig. 2.9). The appendage then arises from the theca where biserial floor plates bearing brachioles lie atop the extraxial elements with a large ovate lumen between that connects with the coelom. Guensburg et al. (2016) dismiss this lumen as being positioned between floor plates and not connected with the extraxial elements, but this is clearly not the case (Fig. 2.9). Furthermore, the lumen penetrates the thecal wall where the appendage attaches to the theca. These appendages do not branch distally.

In Eumorphocystis, the erect floor plates are almost certainly the abradial set. They extend from the distal end of the recumbent ambulacra that are abradial floor plates because of their broad exposure and brachiole placements. The erect floor plates extend in an unbroken series from these plates and continue the biserial arrangement up the erect feeding appendages. They are widely exposed sharing in coelomic extensions up the ambulacrum.

Morphologies seen in crinoids are very similar to those seen in Eumorphocystis but complicated by later evolution. Among the earliest crinoids, protocrinoids appear to have composite appendages formed from axial and extraxial elements (Guensburg and Sprinkle, 2007, 2009; Guensburg et al., 2016). Unusually, crinoids appear to lack brachioles early in their history, but later forms evolve pinnules repeatedly in different clades (Ausich, 1998), showing that such accessory appendages can easily be gained and lost. The floor plates cover a large lumen with underlying brachial plates of extraxial origin. These floor plates in 
some cases may have pores as are known for both adradial and abradial floor plates in different taxa. Later crinoids appear to lose the floor plates and have a large food groove formed along the interior of the brachial elements.

The basic morphology of a food groove formed from floor plates covering an appendage cored with coelomic extension is known from blastozoans, including Eumorphocystis (Fig. 2.9) and solutes (Parsley, 1980), showing that these morphologies are not unique to crinoids as some have suggested (Guensburg and Sprinkle, 2009).

\section{Homologies in Eleutherozoa}

Eleutherozoa remains a great challenge for oral/axial skeletal homologies in Echinodermata. These taxa belong to the pentaradial clade as evidenced by the preponderance of pentaradiate symmetry among taxa, though a few derived clades exhibit unusual ambulacral symmetries. Eleutherozoa is a well-diagnosed group that has been recovered as a clade by several broad analyses supported by a variety of synapomorphies including five-fold symmetry (sensu Sumrall and Wray, 2007), articulating spines, lack of cover plates, jaw structures, inverted posture, vagrant life mode, and others.

The structures of the mouth frame and ambulacral system, however, are highly derived among the various taxa, and there is little understanding of which, if any, of the skeletal elements correspond with elements outlined by the UEH model. Most of these taxa have the derivative of a jaw apparatus that bears 10 paired elements (the dipyramids and auricle elements of echinoids, the mouth angle plates of asteroids and ophiuroids, parapharyngeal ring elements of holothuroids [see Sumrall, 1997]). Whether any of these elements are homologous has not been determined. Interestingly, there seems to be nothing clearly corresponding to the peristomial border of most other pentaradiate echinoderms to suggest homology with elements of UEH. This suggests that either UEH peristomial border systems are evolved within the pentaradiate clade or Eleutherozoa has lost these elements secondarily. Given the fragmented but improving Cambrian echinoderm record and an absence of anything that seems to be an Eleutherozoan (Zamora et al., 2013a), it seems likely that a derived loss in Eleutherozoa is most reasonable.

The only structures that seem to show promise for UEH elements in Eleutherozoa are the ambulacral elements in asterozoans (Fig. 4). Here, there are two pairs of elements that form the food groove, called ambulacrals and adambulacrals, that correspond to the double biserial floor plate elements in other pentaradiate echinoderms. The ambulacrals of asterozoans correspond to the adradial floor plate series of other pentaradial taxa as seen by their position along the midline of the ambulacrum. The adambulacral elements of asterozoans correspond to the abradial set. These plates lie abradially to the ambulacral series. Figure 4 shows a cross-sectional comparison between the plates of asteroids and the edrioasteroid-grade echinoderm Kailidiscus.

\section{Alternative views}

A recent paper by Guensburg et al. (2016) proposed an unconventional model for the origin of crinoids, which they argued were derived from edrioasteroids or stemmed edrioasteroid-like
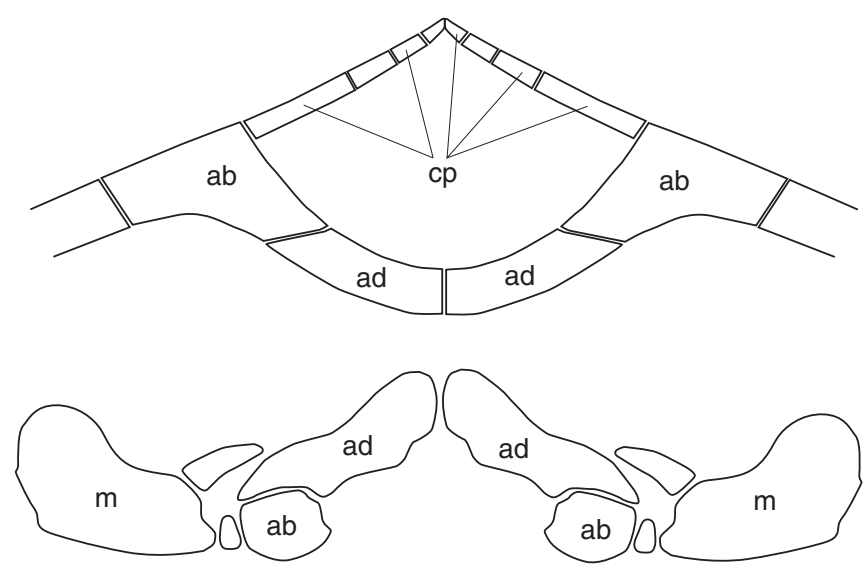

Figure 4. Cross-sectional relationships of ambulacral floor plates in edrioasteroids and asteroids. (1) Cross section of the ambulacrum of Kailidiscus showing adradial and abradial floor plates forming the food groove, which is covered by cover plates. (2) Cross section of the asteroid Luidia showing adradial and abradial floor plates forming the inverted food groove, which lacks cover plates (after Blake, 1980). ab = abradial floor plates (ambulacrals in asteroid terminology); ad = adradial floor plates (adambulacrals in asteroid terminology); $\mathrm{cp}=$ cover plates; $\mathrm{m}=$ mouth.

forms rather than blastozoans. Their argument was based, in large measure, on a rejection of UEH. However, their critique reflects a misunderstanding of both UEH and the modern phylogenetic methodological context in which it was developed. $\mathrm{UEH}$, in and of itself, makes no claim concerning the ancestry of crinoids. That UEH components can be identified in crinoids (see the preceding) speaks only to the fact that crinoids are nested within the pentaradiate echinoderm clade. Crinoid origins can only be addressed through rigorous phylogenetic analysis and inferred a posteriori from the resulting tree topologies. These misunderstandings merit brief discussion.

Most important, the critique presented by Guensburg et al. (2016) confuses a character state with the polarity of a given state at a given part of a phylogeny. Their argument that the echinoderm-wide ancestral plating conditions identified through UEH were simultaneously plesiomorphic and homoplastic, for example, misconstrues basal conditions for a clade with derived conditions in subordinate lineages. A character state can arise multiple times, even after it is secondarily lost, but whether subsequent reacquisitions are considered plesiomorphic is entirely dependent on where on the tree one is looking.

Like other morphological character states, UEH components cannot be described a priori as plesiomorphy, synapomorphy, or homoplasy in the absence of a phylogeny by: (1) presuming them to be present in the last common ancestor of blastozoans and crinoids, (2) interpreting them as independently acquired on the basis of stratigraphic arguments, or (3) interpreting them as independently acquired because of inconsistent distribution among taxa (Guensburg et al., 2016, p. 258). Character state polarity can only be assessed a posteriori. Furthermore, synapomorphies are clade-diagnosing characters, not autapomorphies found in single terminal taxa (contra Guensburg et al., 2016, p. 258).

In fact, the goal of UEH is to identify the homologous structures on which character states can be identified-not to polarize the states themselves. UEH shows how homologous elements are present in presumed descendant lineages independent of how those descendent lineages are related to one another. This is the pure 
essence of the morphological character. The description of a single character suite as 'superficially similar' that 'can be traced back to the plesiomorphic pattern' (Guensburg et al., 2016, p. 256) is incompatible; the former describes homoplasy, and the latter describes homology. A character suite cannot be both. Although the casual a priori dismissal of well-documented ontogenetic and phylogenetic similarity as homoplasy has a long history in echinoderm paleontology (i.e., Jefferies, 1986), it is inconsistent with modern systematic methodology.

Guensburg et al. (2016, p. 254) claim that no specific sister taxon was identified when constructing UEH. In fact, six outgroup taxa were used to polarize a crinoid-inclusive ingroup (Ausich et al., 2015). Regardless, describing sister taxon relationships as 'subjective' and something that 'cannot be rigorously tested' (Guensburg et al., 2016, p. 254) diverges from modern phylogentic methodology and disregards the kind of information available in the literature. UEH data and characters are explicit and published for others to interpret and refine, as were the methods of phylogenetic inference (Ausich, 1998; Ausich et al., 2015). That Guensburg et al. (2016) did not test them by presenting an alternate phylogeny renders them neither subjective nor untestable.

Characters are evidence of relationships, not features that define clades. Clades are defined by ancestry and descent (Rowe, 1988). Guensburg et al. (2016, p. 256) suggest that any sister taxon to crinoids should have calycinal coelomic slots, slat-like floor plates, and podial basins with pores. They suggest that these must either be lost and regained by the pertinent ancestor of crinoids (homoplasy) or are present in yet unknown taxa (plesiomorphy). They omit the obvious (and optimal) third possibility - that these are synapomorphies of crinoids. This third option is consistent with these characters only being present in crinoids and absent in other taxa.

Temporal arguments about the timing of supposed sister taxa of crinoids are meaningless, especially with the patchy fossil record of echinoderms in the late Cambrian (Zamora et al., 2013a). Guensburg et al. (2016) based their argument that crinoids are not descended among blastozoans on a temporal gap of $25 \mathrm{Myr}$ between the earliest crinoid and the earliest blastozoan. This distorts the actual argument because Ausich et al. (2015) used Ordovician, not middle Cambrian, outgroups, and the actual temporal gap was negligible. That Guensburg et al. (2016) used Ordovician forms rather than middle Cambrian edrioasteroids, such as Kailidiscus, suggests an inconsistent approach toward the issue.

\section{Summary}

The common morphology seen in the peristomial border of pentaradiate echinoderms indicates that these structures result from a deep-seated homology. The often-confusing nature of peristomial plate names found across pentaradiate echinoderms typically results from concentrating on differences, rather than the overarching similarity, among taxa. It is, therefore, critical that before coding characters, the oral area and ambulacral system of taxa be interpreted using the UEH model to avoid the pitfalls of coding nonhomologous elements simply based on position or on possessing the same name as a historical artifact. Different expressions of these morphologies among subsets of taxa provide character transformation data for phylogenetic inference.

Evidence suggests that the two series of plates associated with the peristome, oral frame plates and oral plates, are each associated with complementary floor plates (adradial and abradial, respectively). Oral frame plates and adradial floor plates are internal structures that generally cannot be seen from the thecal exterior. They are found in several edrioasteroid-grade and eocrinoid-grade echinoderms. Oral plates and abradial floor plates are externally expressed and are found in most derived blastozoans and crinoids.

Arguments used to dismiss UEH and document the origin of crinoids are incompatible with data and methods. They confuse several issues, including homology versus phylogenetic analysis; the nature of homology; a priori versus a posteriori arguments; homoplasy and plesiomorphy. The simple fact that, barring a few apparently highly derived taxa, UEH is a powerful tool to understand echinoderm morphology suggests that the patterns recognized show a deep-seated underlying homology scheme for pentaradiate echinoderms.

\section{Acknowledgments}

Numerous people helped in the formation of ideas, including W.I. Ausich, C.A. Brochu, B. Deline, T.W. Kammer, R.L. Parsley, S.L. Sheffield, A.B. Smith, J. Sprinkle, and S. Zamora. J. Golden, T. Adrain, S.V. Rozhnov, and J.W. Atwood provided specimens for this study. Funding was provided by the National Geographic Society and NSF grant DEB1036260. T.W. Kammer, J.A Waters, and S. Zamora reviewed this manuscript and provided numerous suggestions for its improvement.

\section{References}

Ausich, W.I., 1998, Early phylogeny and subclass division of the Crinoidea (Phylum Echinodermata): Journal of Paleontology, v. 72, p. 499-510.

Ausich, W.I., and Kammer, T.W., 2016, Exaptation of pelmatozoan oral surfaces: constructional pathways in tegmen evolution: Journal of Paleontology, v. 90, p. 689-720.

Ausich, W.I., Kammer, T.W., Rhenberg, E.C., and Wright, D.F., 2015, Early phylogeny of crinoids within the pelmatozoan clade: Palaeontology, v. 58, p. 937-952.

Bather, F.A., 1914, The edrioasters of the Trenton Limestone (Parts 1 and 2): Geological Magazine, Dec. 4, 5: p. 115-125, 162-171.

Bauer, J.E., Sumrall, C.D., and Waters, J.A., 2017, Hydrospire morphology and its implications for blastoid phylogenetic inference: Journal of Paleontology, doi: https://doi.org/10.1017/jpa.2017.2.

Bell, B.M., 1976, A Study of North American Edrioasteroidea: New York State Museum Memoir, 21, 446 p.

Blake, D.B., 1980, Post-Paleozoic Asterozoa, in Broadhead, T.W., and Waters J.A., eds., Echinoderms: Notes for a Short Course: Knoxville, University of Tennessee, Department of Geological Sciences, p. 200-214.

Bockelie, J.F., 1979, Taxonomy, functional morphology and paleoecology of the Ordovician cystoid family Hemicosmitidae: Palaeontology, v. 22, p. 363-406.

Bodenbender, B.E., and Fisher, D.C., 2001, Stratocladistic analysis of blastoid phylogeny: Journal of Paleontology, v. 75, p. 351-369.

Branson, E.B., and Peck, R.E., 1940, A new cystoid from the Ordovician of Oklahoma: Journal of Paleontology, v. 14, p. 89-92.

Brett, C.E., Frest, T.J., Sprinkle, J., and Clement, C.R., 1983, Coronoidea: a new class of blastozoan echinoderms based on a taxonomic reevaluation of Stephanocrinus: Journal of Paleontology, v. 57, p. 627-651.

Broadhead, T.W., and Sumrall, C.D., 2003, Heterochrony and paedomorphic development of Sprinkleocystis ektopios, new genus and species (Rhombifera, Glyptocystida) from the Middle Ordovician (Carodoc) of Tennessee: Journal of Paleontology, v. 77, p. 113-120. 
David, B., and Mooi, R., 1998, Major events in the evolution of echinoderms viewed by the light of embryology, in Mooi, R., and Telford, M., eds. Echinoderms, San Francisco: Rotterdam, Balkema, p. 21-28.

David, B., Lefebvre, B., Mooi, R., and Parsley, R.L., 2000, Are homalozoans echinoderms? An answer from the extraxial-axial theory: Paleobiology, v. 26 , p. $529-555$.

Donovan, S.K., and Paul, C.R.C., 1985, Coronate echinoderms from the lower Palaeozoic of Britain: Palaeontology, v. 28, p. 527-543.

Foerste, A.F., 1938, Echinodermata, in Resser, C.E., and Howell, B.F., eds., Lower Cambrian Olenellus zone of the Appalachians: Bulletin of the Geological Society of America, v. 49, p. 212-213.

Frest, T.J., and Strimple, H.L., 1982, A new comarocystitid (Echinodermata: Paracrinoidea) from the Kimmswick Limestone (Middle Ordovician), Missouri: Journal of Paleontology, v. 56, p. 358-370.

Frest, T.J., Strimple, H.L., and Paul, C.R.C., 2011, The North American Holocystites fauna (Echinodermata, Blastozoa: Diploporita): paleobiology and systematics: Bulletins of American Paleontology, v. 380, p. 141

Guensburg, T.E., and Sprinkle, J., 2007, Phylogenetic implications of the Protocrinoidea: Blastozoans are not ancestral to crinoids: Annales de Paléontologie, v. 93, p. 277-290.

Guensburg, T.E., and Sprinkle, J., 2009, Solving the mystery of crinoid ancestry: new fossil evidence of arm origin and development: Journal of Paleontology, v. 83, p. 350-364.

Guensburg, T.E., and Sprinkle, J., 2010, Emended restoration of Titanocrinus sumralli Guensburg and Sprinkle, 2003 (Echinodermata, Crinoidea) Journal of Paleontology, v. 84, p. 566-568.

Guensburg, T.E., Blake, D.B., Sprinkle, J., and Mooi, R., 2016, Crinoid ancestry without blastozoans: Acta Palaeontologica Polonica, v. 61, p. 253-266.

Jefferies, R.P.S., 1986, The Ancestry of the Vertebrates: London, British Museum (Natural History), $376 \mathrm{p}$.

Kammer, T.W., Sumrall, C.D., Ausich, W.I., Deline, B., and Zamora, S., 2013, Oral region homologies in Paleozoic crinoids and other plesiomorphic pentaradial echinoderms: PLoS One, v. 8, e77989.

Kesling, R.V., 1967, Cystoids, in Moore, R.C., ed., Treatise on Invertebrate Paleontology: New York and Lawrence, Geological Society of America and University of Kansas, p. s86-262.

Meek, F.B., 1871, On some new Silurian crinoids and shells: American Journal of Science, ser, 3, p. 295-299.

Mooi, R., and David, B., 1997, Skeletal homologies of echinoderms, in Waters, J.A., and Maples, C.G., eds., Geobiology of Echinoderms: Paleontological Society papers, v. 3, p. 305-335.

Mooi, R., and David, B., 1998, Evolution within a bizarre phylum: homologies of the first echinoderms: American Zoologist, v. 38, p. 965-974.

Mooi, R., and David, B., 2008, Radial symmetry, the anterior/posterior axis, and echinoderm Hox genes: Annual Review of Ecology, Evolution, and Systematics, v. 39, p. 43-62.

Mooi, R., David, B., and Marchand, D., 1994, Echinoderm skeletal homologies: classical morphology meets modern phylogenetics, in David, B., Guille, A., Féral, J., and Roux, M., eds., Echinoderms Through Time: Rotterdam, A. A Balkema, p. 87-95.

Mooi, R., David, B., and Wray, G.A., 2005, Arrays in rays: terminal addition in echinoderms and its correlation with gene expression: Evolution and Development, v. 7, p. 542-555.

Owen, D.D., and Shumard, B.F., 1850, Descriptions of fifteen new species of Crinoidea from the Subcarboniferous limestone of Iowa, Wisconsin and Minnesota in the years 1848-1849: Journal of the Academy of Natural Sciences of Philadelphia, ser. 2, v. 2, p. 89-94

Parsley, R.L., 1980, Homalozoa, in Broadhead, T.W., and Waters J.A., eds., Echinoderms: Notes for a Short Course: Knoxville, University of Tennessee, Department of Geological Sciences, p. 200-214.

Parsley, R.L., 1982, Eumorphocystis, in Sprinkle, J., ed., Echinoderm Faunas from the Bromide Formation (Middle Ordovician) of Oklahoma: University of Kansas Paleontological Contributions, Monograph, v. 1, p. 106-117.

Parsley, R.L., and Mintz, L.W., 1975, North American Paracrinoidea (Ordovician, Paracrinozoa, New, Echinodermata): Bulletins of American Paleontology, v. 68, p. 5-115.

Parsley, R.L., and Zhao, Y., 2006, Long stalked eocrinoids in the basal Middle Cambrian Kaili Biota, Taijiang County, Guizhou Province, China: Journal of Paleontology, v. 80, p. 1058-1071.

Patterson, C., 1988, Homology in classical and molecular biology: molecular biology and evolution, v. 5, p. 603-625.

Paul, C.R., 1971, Revision of the Holocystites fauna (Diploporita) of North America: Fieldiana Geology, v. 24, p. 1-166.

Paul, C.R.C., 1988, The phylogeny of the cystoids, in Paul, C.R.C., and Smith, A.B., eds., Echinoderm Phylogeny and Evolution: Oxford, Clarendon Press, p. 199-213.

Paul, C.R.C., and Smith, A.B., 1984, The early radiation and phylogeny of echinoderms: Biological Reviews, v. 59, p. 443-481.
Rowe, T., 1988, Definition, diagnosis, and origin of Mammalia: Journal of Vertebrate Paleontology, v. 8, p. 241-264.

Sheffield, S.L., and Sumrall, C.D., 2015, A new interpretation of the oral plating patterns of the Holocystites fauna (Diploporita: Echinodermata), in Zamora, S., and Rábano, I., eds., Progress in Echinoderm Paleobiology: Cuadernos del Museo Geominero, 19: Madrid, Instituto Geológico y Minero de España, p. $159-162$

Sheffield, S.L., and Sumrall, C.D., 2017, A revision of the Holocystites (Diploporita: Echinodermata) fauna: Journal of Paleontology, doi: https:// doi.org/10.1017/jpa.2016.159.

Smith, A.B., 1984, Classification of the Echinodermata: Palaeontology, v. 27, p. $431-459$.

Smith, A.B., 1990, Evolutionary diversification of echinoderms during the early Palaeozoic, in Taylor, P.D., and Larwood, G.P., eds., Systematics Association Special Volume 42: Oxford, Clarendon Press, p. 256-286.

Sprinkle, J., 1973, Morphology and Evolution of Blastozoan Echinoderms Harvard University Museum of Comparative Zoology, Special Publication, $283 \mathrm{p}$.

Sprinkle, J., 1975, The "arms" of Caryocrinites, a rhombiferan cystoid convergent on crinoids: Journal of Paleontology, v. 49, p. 1062-1073.

Sprinkle, J., and Parsley, R.L., 1982, "Golf-ball" paracrinoids, in Sprinkle, J., ed., Echinoderm Faunas from the Bromide Formation (Middle Ordovician) of Oklahoma: University of Kansas Paleontological Contributions, Monograph, 1, p. 224-230.

Sprinkle, J., and Sumrall, C.D., 2008, New parablastoid taxa from North America: The University of Kansas Paleontological Contributions, v. 16 , p. 1-14.

Stumm, E.C., 1955, Three new species of the cystid genus Lipsanocystis from the Middle Devonian of the Traverse Group of Michigan: Contributions from the Museum of Paleontology, University of Michigan, v. 12, p. $97-103$.

Sumrall, C.D., 1996, Late Paleozoic edrioasteroids (Echinodermata) from the North American midcontinent: Journal of Paleontology, v. 70, p. 969-985.

Sumrall, C.D., 1997, The role of fossils in the phylogenetic reconstruction of Echinodermata, in Waters, J.A., and Maples, C.G., eds., Geobiology of Echinoderms: Paleontological Society Papers, v. 3, p. 267-288.

Sumrall, C.D., 2008, The origin of Lovén's Law in glyptocystitoid rhombiferans and its bearing on the plate homology and the heterochronic evolution of the hemicosmitid peristomal border, in Ausich, W.I., and Webster, G.D., eds., Echinoderm Paleobiology: Bloomington, University of Indiana Press, p. 228-241.

Sumrall, C.D., 2010, A model for elemental homology for the peristome and ambulacra in blastozoan echinoderms, in Harris, L.G., Böttger, S.A., Walker, C.W., and Lesser, M.P., eds., Echinoderms: Durham: London, CRC Press, p. 269-276.

Sumrall, C.D., 2015, Understanding the oral area of derived stemmed echinoderms, in Zamora, S., and Rábano, I., eds., Progress in Echinoderm Paleobiology: Cuadernos del Museo Geominero, 19: Madrid, Instituto Geológico y Minero de España, p. 169-174.

Sumrall, C.D., and Deline, B., 2009, A new species of the dual-mouthed paracrinoid Bistomiacystis and a redescription of the edrioasteroid Edrioaster priscus from the Middle Ordovician Curdsville Member of the Lexington Limestone: Journal of Paleontology, v. 83, p. 135-139.

Sumrall, C.D., and Parsley, R.L., 2003, Morphology and biomechanical implications of isolated discocystinid plates (Edrioasteroidea, Echinodermata) from the Carboniferous of North America: Palaeontology, v. 46 , p. $113-138$.

Sumrall, C.D., and Waters, J.A., 2012, Universal elemental homology in glyptocystitoids, hemicosmitoids, coronoids and blastoids: steps toward echinoderm phylogenetic reconstruction in derived blastozoa: Journal of Paleontology, v. 86, p. 956-972.

Sumrall, C.D., and Wray, G.A., 2007, Ontogeny in the fossil record: diversification of body plans and the evolution of "aberrant" symmetry in Paleozoic echinoderms: Paleobiology, v. 33, p. 149-163.

Sumrall, C.D., and Zamora, S., 2011, Ordovician edrioasteroids from Morocco: faunal exchanges across the Rheic Ocean: Journal of Systematic Palaeontology, v. 9, p. 425-454.

Sumrall, C.D., Sprinkle, J., and Guensburg, T.E., 1997, Systematics and paleoecology of late Cambrian echinoderms from the western United States: Journal of Paleontology, v. 71, p. 1091-1109.

Sumrall, C.D., Brett, C E., Dexter, T.A., and Bartholomew, A., 2009, An enigmatic blastozoan fauna from central Kentucky: Journal of Paleontology, v. 83, p. $739-749$.

Ubaghs, G., 1963, Rhopalocystis destombesi n. g., n. sp., éocrinoïde de 1494 l'Ordovicien inférieur (Trémadocien supérieur) du Sud marocain: Notes et 1495: Mémoires du Service géologique du Maroc, v. 172, p. 25-45.

Wanner, J., 1916, Die Permischen echinodermen von Timor, I. Teil: Palaontologie von Timor, v. 11, p. 1-329. 
Whiteaves, J.F., 1887, On some fossils from the Hamilton Formation of Ontario, with a list of the species present known from that formation and province: Contributions to Canadian Palaeontology, v. 1, p. 91-125.

Zamora, S., and Smith, A.B., 2011, Cambrian stalked echinoderms show unexpected plasticity of arm construction: Proceedings of the Royal Society of London B: Biological Sciences, v. 279, p. 293-298.

Zamora, S., and Smith, A.B., 2012, Cambrian stalked echinoderms show unexpected plasticity of arm construction: Proceedings of the Royal Society of London, B, v. 279, p. 293-298.

Zamora, S., Lefebvre, B., Âlvaro, J.J., Clausen, S., Elicki, O., Fatka, O., Jell, P., Kouchinsky, A., Lin, J.P., Nardin, E., Parsley, R., Rozhnov, S.V., Sprinkle, J., Sumrall, C.D., Vizcaïno, D., and Smith, A.B., 2013a, Cambrian echinoderm diversity and palaeobiogeography: Geological Society, London, Memoirs, v. 38, p. 157-171.
Zamora, S., Sumrall, C.D., and Vizcaïno, D., 2013b, Morphology and ontogeny of the Cambrian edrioasteroid echinoderm Cambraster cannati from western Gondwana: Acta Palaeontologica Polonica, v. 58, no. 3, p. 545-559.

Zamora, S., Lefebvre, B., Hosgör, I., Franzen, C., Nardin, E., Fatka, O., and Álvaro, J.J., 2015, The Cambrian edrioasteroid Stromatocystites (Echinodermata): Systematics, palaeogeography, and palaeoecology: Geobios, v. 48, p. 417-426.

Zhao, Y., Sumrall, C.D., Parsley, R.L., and Peng, J., 2010, Kailidiscus, a new plesiomorphic edrioasteroid from the basal middle Cambrian Kaili Biota of Guizhou Province, China: Journal of Paleontology, v. 84, p. 668-680.

Accepted 22 February 2017 